\title{
Peran Strategis Hukum Keluarga (Al-Ahwal Al Syakhsyiyah) Dalam Penguatan Sistem Peradilan Agama Di Indonesia
}

\author{
Hadi Tuasikal \\ Fakultas Hukum, Universitas Muhammadiyah Sorong \\ Email : hadilessytuasikal@gmail.com
}

\begin{abstract}
Abstrak
Dalam sudut pandang ini, sulit memisahkan antara hukum keluarga dengan penguatan sistem peradilan agama di indonesia. Antara keduanya terdapat hubungan yang bersifat simbiosis mutualisme. Di mana perkembangan lembaga peradilan Agama yang tumbuh pesat membutuhkan sistem hukum dan peradilan yang efektif guna menjamin terwujudnya kepastian hukum dan menjaga kepercayaan masyarakat maupun pihak lain yang terkait dengan kewenangannya terutama dalam bidang hukum keluarga. Selain substansi hukum keluarga (al-Ahwal al-Syakhsyiyah) tersebut maka tentu fakultas Syariah/hukum jurusan al-Ahwal al-Syakhsyiyah memiliki peran yang sama dalam membidani lahirnya sumber daya manusia yang andal dan profesional sebagai aparatur hukum di lingkungan peradilan Agama, baik sebagai hakim, panitera, jurusan instansi lainnya.
\end{abstract}

Kata Kunci : Hukum Islam, Hukum Keluarga, Peradilan Agama

\section{PENDAHULUAN}

Pembahasan seputar hukum keluarga dengan segala dimensi kajiannya memiliki peran strategis dalam penguatan sistem peradilan Agama di Indonesia dan tentu selalu menarik untuk didiskusikan. Alasan terpenting dari paradigma tersebut, adalah karena hukum keluarga islam merupakan bidang hukum islam yang paling banyak diterapkan secara luas dan langsung oleh negara-negara muslim di dunia, termasuk indonesia. Hukum keluarga lslam telah menjadi dasar bagi masyarakat muslim selama berabad-abad dan merepresentasikan bagian paling pokok dari syariah.

Dalam hukum lslam, istilah hukum keluarga dikenal dengan al-ahwal al-Syakhsyiyah yang merupakan istilah bagi keseluruhan hukum yang menyangkut masalah keluarga dan peradilan islam, seperti hukum perkawinan, kewarisan, wasiat, dan hibah. Istilah hukum keluarga sejatinya pertama kali muncul dari sistem hukum yang berlaku di Eropa dan memiliki pengaruh cukup kuat dalam proses kodifikasi hukum di negara-negara berpenduduk Muslim.

Munculnya istilah hukum keluarga di dunia islam pertama kali pada tahun 1893 ketika seorang hakim terkemuka Mesir, Muhammad Qadri Pasha mengkompilasi kaidahkaidah hukum keluarga dalam tulisannya berjudul al-Ahkam al-Shar'iyyat fi al-Ahwal alSyakhsyiyyat ala Mazhab al lmam Abi Hanifa al-Nu'man. Kompilasi ini memuat 646 pasal yang berisi kaidah-kaidah hukum berdasarkan Mazhab Hanafi tentang perkawinan, 
perceraian, mahar, larangan, wasiat, dan warisan. Oleh karena itu dapa ditegaskan bahwa modernisasi hukum keluarga di dunia isalam yang meliputi aspek perkawinan, perceraian, dan waris secra fenomenal telah dimulai sejak awal abad ke-20.

Terjadi fenomena hukum yang unik pada pengadilan Agama, di mana sebagian besar peranannya sebagai peradilan keluarga, meskipun sebelumnya tidak didesain untuk tugas tersebut. Dengan kondisi objektif ini, maka peradilan Agama menjadi titik sentral utama pengembangan hukum keluarga islam di indonesia. Berdasarkan paradigma tersebut, tentu saja dapat pula dipahami sebaliknya, bahwa hukum keluarga (Al-Ahwal Al-Syakhsyiyah) memiliki peran strategis dalam penguatan sistem peradilan Agama di idonesia, karena semakin kuat eksistensi hukum keluarga (Al-Ahwal Al-Syakhsyiyah), maka semakin kuat pula eksistensi peradilan agama di indonesia. Berdasarkan latar belakang di atas, maka permasalahan yang hendak dibahas dalam makalah ini adalah sebagai berikut; (1) Bagaimana peran strategis hukum keluarga (al-Ahwal al-Syakhsyiyah) di indonesia?; (2) Bagaimana penguatan sistem peradilan Agama di indonesia dari korelasinya dengan fakultas Syariah/hukum jurusan hukum keluarga (al-Ahwal al-Syakhsyiyah)?

\section{PEMBAHASAN}

\section{Peran Strategis Hukum Keluarga (Al-Ahwal Al-Syakhsyiyah) di Indonesia}

Peran strategis hukum keluarga (al-Ahwal al-Syakhshiyyah) dan fakultas Syariah/hukum jurusan al-Ahwal al-Syakhsyiah dapat terbaca dalam visi jurusan ini, yaitu membentuk sarjana yang mampu mengembangkan hukum islam. Khususnya hukum keluarga baik materiil maupun formil serta mampu mengaplikasikan untuk kepentingan pribadi maupun masyarakat. Selain itu, dipertegas pula dalam misi jurusan ini, yaitu: pertama, menciptakan yang mampu menguasai dan mengembangkan hukum Islam dari hukum positif khususnya hukum keluarga baik hukum materiil maupun hukum formil. Kedua, menciptakan mahasiswa yang profesional dan mampu mengaplikasikan pengetahuan di bidangnya dalam berbagai profesi seperti hakim, panitera, pengacara, kepenghuluan, konsultan hukum ahli hisab-rukyat dan administrator di berbagai lembaga peradilan dan Kantor Urusan Agama. Visi dan misi jurusan ini dikuatkan lagi dengan tujuannya, yakni membentuk sarjana yang ahli di bidang hukum keperdataan Islam serta profesional dalam mengaplikasikannya di tengah-tengah masyarakat Lebih luas peran strategis jurusan hukum keluarga (al-Ahwal alSyakhshiyyah) dapat pula dipahami dalam visi dan misi fakultas Syariah, yaitu: sebagai pendidikan tinggi yang berupaya melahirkan alumni yang berkualitas, profesional di bidang ilmuwan hukum dan parktisi hukum dengan tujuan memberikan penguatan bagi 
perkembangan sistem peradilan Agama indonesia. Oleh karena itu, setiap lulusan jurusan hukum keluarga (al-Ahwal al-Syakhshiyyah) setidaknya memiliki dua kompetensi sebagai berikut; pertama, memiliki kemampuan dan keahlian dalam Bidang Hukum Keluarga Islam, yang meliputi hukum perkawinan, kawarisan, wasiat, hibah, sedekah, wakaf, dan urusan haji, serta memahami pranata hukum Islam lainnya. Kedua, memiliki kemampuan dan keahlian dalam bidang hukum Acara dan penerapannya di pengadilan Agama.

Hukum keluarga (al-Ahwal al-Syakhsiyah) merupakan hukum yang telah dilaksanakan di dunia Islam, bahkan telah menjadi budaya hukum masyarakat. Sehingga kesadaran untuk menerapkan hukum keluarga di dunia Islam sangat Tinggi, bukan saja di negara-negara Islam atau negara-negara sekuler di mana kaum muslimin menjadi penduduk yang minoritas pun hukum keluarga Islam ini diterapkan dan ditaati oleh keluarga-keluarga muslim, seperti di Birma, Singapura, dan Filipina Selatan (Mindanau).

Keberadaan hukum islam sangat penting, selain sebagai bahan baku bagi penyusunan hukum nasional. Juga menjadi inspirator dan dinamisator dalam pengembangan hukum nasional. Hukum islam sangat dekat dengan sosio-antropologis bangsa indonesia, sehingga kehadirannya dapat dengan mudah diterima oleh masyarakat indonesia. ada, dan merupakan benteng terakhir di dalam mempertahankan diri terhadap pengaruh hukum barat yang diterapkan pemerintah kolonial di dunia Islam yang merupakan daerah jajahannya. Di sisi lain hukum bidang keluarga ini diperkenalkan oleh para ulama kepada masyarakat melalui dakwahnya dan sekaligus memberikan contoh pelaksanaannya didalam kehidupan seharihari, sehingga betul-betul meningkatkan kesadaran hukum masyarakat, dan menjadikan hukum islam di bidang hukum keluarga ini menjadi hukum adatnya.

Persoalan yang berkembang di seputar hukum keluarga adalah masih banyaknya perbedaan perbedaan pendapat di kalangan umat islam, begitu juga dalam penerapan hukum keluarga di dunia Islam ternyata masih banyak terjadi perbedaan pendapat, hal ini disebabkan karena terdapat para ulama serta lembaga-lembaga pendidikan merujuk kepada mazhab tertentu, maka wajar apabila dibanyak negara warna mazhab masih tampak di dalam undangundang hukum perkawinannya.

Banyak kaidah fikih yang ruang lingkup dan cakupannya lebih sempit dan isi kandungannya lebih sedikit. Kaidah yang semacam ini hanya berlaku dalam cabang-cabang fikih tertentu, dan disebut al-Qowa'id al-fiqhiyah al-Khashshah atau juga di sebut al-Dhabith oleh sebagian ulama.

Kemudian dalam pembidangannya pun berbeda, ada yang membidangkan kepada empat bidang saja, yaitu bidang ibadah, bidang jual beli, bidang pengakuan, dan bidang 
munakahat. Tetapi ada juga yang membaginya kepada bidang ibadah mahdah, bidang alahwal al-syakhsiyah, bidang muamalah, bidang jinayah, dan bidang al-aqdiyah.

Pembidangan ini pun dapat dikembangkan lagi sesuai dengan perkembangan ilmu hukum islam dan sesuai dengan perkembangan kebutuhan masyarakar itu sendiri. Kaidah yang khusus di bidang al-ahwal al-syakhshiyah menjadi penting karena perhatian sumber hukum islam yaitu Alquran dan al-Hadits kepada masalah-masalah keluarga sangat besar. Hal ini terbukti jumlah ayat yang berhubungan dengan hukum keluarga menmpati urutan kedua setelah ibadah mahdhah. Artinya, Alquran dan al-Hadits setelah memberi tuntunan yang cukup untuk pembinaan pribadi muslim dengan ajaran ibadah mahdhah, kemudian beralih kepada pembinaan kehidupan keluarga muslim yang menjadi unsur terkecil dalam pembinaan masyarakat dan komunitas muslim. Penerapan sistem hukum keluarga islam dan sistem peradilan Islam merupakan suatu keniscayaan dan imperatif Pada dasarnya, hukum indonesia menghendaki berkembangnya kehidupan beragama dan hukum agama dalam kehidupan hukum nasional. Hukum nasional yang dikehendaki oleh negara adalah hukum yang menampung dan memasukkan hukum agama, dan tidak memuat norma hukum yang bertentangan dengan hukum agama.

Bila dicermati peranan hukum Islam dalam pembangunan hukum nasional, maka ada beberapa fenomena yang bisa dijumpai dalam praktiknya, yaitu pertama, hukum islam berperan dalam mengisi kekosongan hukum dalam hukum positif. Dalam hal ini hukum islam diberlakukan oleh negara sebagai hukum positif bagi umat islam. Kedua, hukum islam berperan sebagai sumber nilai yang memberikan kontribusi terhadap aturan hukum yang dibuat. Oleh karena aturan hukum tersebut bersifat umum, tidak memandang perbedaan agama, maka nilai-nilai hukum islam dapat berlaku pula bagi seluruh warga negara.

Penerapan hukum keluarga islam harus dipandang dengan memakai teori kredo yang memiliki kaitan yang erat dengan penyerapan hukum. Teori pertama tentang penyerapan hukum adalah teori receptio in complexu yang dirumuskan oleh Lodewijk Willem Cristian van den Berg. Sebelumnya teori ini juga disebutkan oleh H.A.R. Gibb, Menurut teori ini hukum yang berlaku bagi seseorang adalah hukum agama yang dianutnya. Kebetulan di indonesua mayoritas beragama Islam maka hukum yang berlaku adalah hukum islam walaupun dalam pelaksanaannya masih terdapat sedikit penyimpangan-penyimpangan. Secara fakta, teori van den Berg lebih rinci dibandingkan teori yang dikemukakan H.A.R. Gibb, sebab praktiknya hingga sekarang umat Islam di Indonesia Masih Banyak yang Belum taat dalam menjalankan ajaran islam. Ketaatan mereka masih terbatas pada salat lima waktu, zakat, puasa dan haji, sedangkan ajaran islam lainnya masih kurang diperhatikan. Tidaklah 
berlebihan jika dikatakan bahwa hukum islam di Indonesia adalah hukum yang hidup (the living law), kendati secara resmi dalam aspek-aspek pengaturan tertentu, ia tidak atau belum dijadikan kaidah hukum positif oleh negara. Untuk mewujudkan anggapan tersebut maka dibutuhkan aktualisasi hukum islam itu sendiri, agar tetap urgen menjadi bagian dari proses pembangunan hukum nasional.

Aktualisasi hukum islam dapat dibedakan menjadi dua bentuk yaitu: pertama, upaya pemberlakuan hukum Islam dengan pembentukan pengaturan hukum tertentu yang berlaku khusus bagi umat islam. Kedua, upaya menjadikan hukum islam sebagai sumber hukum bagi penyusunan hukum nasional. Dengan demikian, jurusan hukum keluarga menempati peran strategis dalam penguatan sistem peradilan peran tersebut, selain menguatkan kewenangan pengadilan Agama juga memberikan konstribusi terhadap pengembangan hukum keluar yang menjadi bagi peradilan Agama.

Peran strategis jurusan hukum keluarga (Ahwal al-Syakhshiyyah) yang sangat signifikan sebagaimana diuraikan di atas, diragukan oleh berbagai pihak karena munculnya beberapa perubahan besar dalam perguruan tinggi islam di indonesia. Sebagai harapan terbesar bagi umat islam pada umumnya, dan bagi Peradilan Agama pada khususnya terdapat perubahan yang dikritisi oleh umat islam indonesia terhadap eksistensi jurusan hukum keluarga yang berada dalam cakupan Perguruan tinggi Islam, yaitu adanya upaya mensekulerkan perguruan tinggi Islam dan para lulusannya. Upaya tersebut dapat dirasakan dalam dua hal penting sebagai berikut; (a) Berubahnya institut menjadi universitas, hal ini dianggap oleh sebagian cendekiawan muslim sebagai perubahan mendasar, karena adanya upaya mengsekulerkan IAIN yang sejak berdirinya bertugas menjadi the guardian of Islam tetapi sekarang digiring untuk menjadi universitas umum seperti kebanyakan perguruan tinggi lainnya Berubahnya gelar keserjanaan keislaman menjadi umum, hal ini dianggap menghilangkan identitas keislaman; (b) Mulai tahun 2016, lulusan perguruan Tinggi Agama di Bawah Kementrian agama akan menyandang gelar kesersarjanaan yang berbeda dari sebelumnya. Sejumlah gelar akademik baik sarjana SI, S2, Dan S3 yang berlaku sejak tahun 2009 melalui peraturan Kementrian Agama (PERMENAG) Nomor 36 Tahun 2009, secara resmi dinyatakan tidak berlaku lagi dengan dikeluarkannya PERMENAG RI Nomor 33 Tahun 2016 tentang Gelar Akademik Perguruan Tinggi Keagamaan. Dalam peraturan baru ini sarjana Fakultas Syariah bergelar Sarjana Hukum (S.H.). peraturan ini telah ditetapkan dan diundangkan pada tanggal 09 Agustus 2016 serta telah dicatat dalam Berita Negara 1170 Tahun 2016. 
Terlepas dari pro dan kontra terhadap perubahan tersebut, jurusan hukum keluarga tetap menjadi harapan bagi umat Islam, memiliki peluang (opportunities) yang sangat besar karena peranannya yang sangat strategis untuk mengisi berbagai jabatan di peradilan Agama, seperti hakim, panitera, juru sita. Hal ini disebabkan karena lulusan jurusan hukum keluarga dipercaya sudah dibekali dengan ilmu dan kemampuan untuk mengisi posisi strategis tersebut dan juga tentu mampu mengisi jabatan lainnya seperti advokat, kepolisian, di komisi-komisi negara, perbankan syariah, notaris syariah, politikus,dan lain sebagainya.

Perubahan gelar keserjanaan merupakan kekuatan (strenght) untuk berkompetisi dengan sarjana hukum lulusan perguruan tinggi lainnya, di samping itu penduduk indonesia mayoritas beragama islam menjadi potensi pendukung bagi para slumni ke depan terlebihlebih lagi para alumni yang sebagian besar berasal dari pesantren tentunya masih dapat dipercaya memiliki integritas tinggi.

Menurut Abdul Manan, terdapat beberapa kelemahan (weaknesse) bagi lulusan perguruan tinggi Islam di Indonesia yang harus diperbaiki dan ditingkatkan yaitu penguasaan beberapa bahasa asing baik aktif maupun pasif serta memperluas wawasan agar tidak terkesan eksklusif dan berpikiran sempit. Lebih lanjut Abdul Manan memberikan contoh dengan perumpamaan, bahwa lulusan perguruan tinggi Islam harus memiliki Channel seperti indovision sehingga dapat menjangkau siaran yang lebih luas, dan tidak hanya terbatas pada siaran lokal saja.

Selain itu, lulusan perguruan tinggi Islam, khususnya fakultas Syariah juga harus tetap waspada terhadap ancaman yang terus eksis, seperti kentalnya faham teori Receptie yang dikemukakan oleh Snouck Hurgronje (1857-1936) yang masih dirasakan mendikotomi hukum Islam dengan hukum Nasional. Begitu pula dari dunia internasional yang terus menyebabkan Islamophobie dengan menggunakan segala cara untuk memojokkan islam dan umat muslim, sehingga timbul kekhawatiran terhadap islam yang selalu diberi label teroris, ekstremis, fundamentalis, dan lain sebagainya.

Tantangan (threats) yang sekarang sedang dihadapi oleh para alumni, yaitu harus mampu menghadapi persaingan Masyarakat Ekonomi Asean (MEA) yang memberikan peluang persaingan bebas arus perdagangan dan jasa juga termasuk pasar tenaga kerja profesional seperti advokat, dokter, akuntan, ahli perbankan, dan lainnya, demikian pula dengan adanya perjanjian internasional seperti AFTA (Asean Free Trade Area), NAFTA (Nort Atlantic Trade Agreement) yang semua itu merupakan tantangan sekaligus ancaman buat para alumni fakultas Syariah dan Hukum. 


\section{Penguatan Sistem Peradilan Agama di Indonesia dan Korelasinya dengan Jurusan Hukum Keluarga (Al-Ahwal Al-Syakhsyiyah)}

Peradilan Agama merupakan representasi dari eksistensi hukum Islam di Indonesia. Oleh karena itu, pembahasan terhadap Peradilan Agama tidak terlepas dari sejarah hukum Islam di Indonesia. Hukum adalah Persyarat mewujudkan masyarakat yang tertib dan berkeadilan. Karena hukum adalah merupakan gejala, fenomena pergaulan. Hukum sebagai gejala pergaulan, sebenarnya tidak hanya menyangkut lapangan pekerjaan dan perbuatan lahir dari manusia saja, tetapi pergaulan hidup manusia adalah merupakan suatu Interdependesi psychis.

Berkaitan dengan penguatan sistem Peradilan Agama, setidaknya terdapat dua hal penting yang berkaitan dengan peran strategis jurusan hukum keluarga (al-Ahwal alSyakhsyiyah), yaitu sebagai berikut; (a) Penguatan Sistem Hukum Peradilan Agama.

Sejauh ini peranan peradilan Agama di Indonesia jauh lebih progresif dibandingkan dengan lembaga sejenisnya yang berada di negara-negara berpenduduk mayoritas muslim. Produk hukum yang hasilkan oleh lembaga Peradilan Agama telah menunjukkan bahwa hukum Islam tidak hanya dihasilkan lewat ijtihad para ulama tetapi juga oleh para hakim lewat putusannya. Oleh karena itu, hukum islam dapat ditemukan pada empat tempat berbeda, yaitu: kitab-kitab fikih, fatwa-fatwa ulama, undang-undang, dan putusan pengadilan.

Progresitivas lembaga peradilan Agama ternyata mampu mereposisi putusan-putusan pengadilan atas hukum islam lainnya yang telah berkembang lebih dahulu. Kenyataan ini disebabkan materi fikih sering kali tidak sesuai dengan kasus yang diajukan ke pengadilan, sementara itu pengaturan dalam undang-undang cenderung tidak lengkap, sehingga wajar jika putusan pengadilan mempunyai posisi penting dalam pembaruan hukum islam.

Disinilah etak signifikannya peran jurusan hukum keluarga (al-Ahwal al-Syakhsyiyah) dalam penguatan sistem hukum Peradilan Agama, di mana lulusan lembaga ini dapat menjadi hakim Peradian Agama yang progresif dalam mereformasi hukum keluarga di indonesia. Jika dilihat berbagai putusan dan penetapan yang dibuat oleh hakim Peradilan Agama diseantero Indonesia, banyak pembaruan hukum keluarga yang sudah dilakukan melalui Judicial activism dengan metode penemuan hukum, terobosan hukum, maupun penafsiran hukum. pada dasarnya, reformasi itu terjadi hari per hari melalui proses penyelesaian hukum keluarga yang kian hari makin kompleks.

Cara pandang dan interpretasi yang berbeda dalam keanekaragaman pemahaman orang islam terhadap hakikat hukum islam telah berimplikasi dalam sudut aplikasinya. Beberapa hal yang ikut berkontribusi dalam memperkaya bidang pemikiran hukum islam, 
sebagaimana dijelaskan di atas diyakini memberi pengaruh cukup besar dalam proses transformasi hukum islam di lndonesia, terutama dalam independensi dan pengembangan Peradilan Agama pasca one roof system di bawah Mahkamah Agung.

Eksistensi jurusan hukum keluarga semakin penting dalam penguatan Peradilan Agama dengan lahirnya Undang-Undang Nomor 3 Tahun 2006 tentang Perubahan atas Undang-Undang Nomor 1 Tahun 1989 tentang Peradilan Agama. Pada prinsipnya, undangundang ini merupakan respons terhadap dinamika dan kebutuhan masyarakat, dengan memberikan perluasan kewenangan kepada Pengadilan Agama Sebagaiman terdapat dalam Pasal 49. Berdasarkan pasal ini, Pengadilan Agama bertugas dan menyelesaikan perkara di tingkat Pertama antara orang-orang yang beragama islam di bidang perkawinan, waris, wasiat, hibah, wakaf, zakat, infak, sedekah, dan ekonomi syariah.

Dalam bidang perkawinan Pengadilan Agama maempunyai kewenangan absolut dalam mengadili dan menyelesaikan masalah penetapan pengangkatan anak berdasarkan hukum islam. Sebelum lahirnya Undang-Undang Nomor 3 Tahun 2006 kewenangan Peradilan Agama dalam Pengangkatan anak yang merupakan bagian dari bidang perkawinan sering dipertanyakan banyak pihak meskipun telah lama di praktikkan. Kini perkara pengangkatan anak di peradilan Agama telah mendapat landasan hukum yang kuat dan jelas.

Perubahan signifikan lainnya dari Undang=Undang Nomor 3 Tahun 2006 adalah mengenai subjek hukum yang di perluas menjadi tidak hanya orang islam dalam pengertian teologis, akan tetapi termasuk orang atau badan hukum yang menundukkan diri secaraa sukarela kepada hukum islam. Pilihan hukum dalam perkara waris (alinea 2 penjelasan Umum Undang-Undang Nomor 7 Tahun 1989) dihilangkan. Dengan demikian, perkara kewarisan bagi orang islam mutlak menjadi kewenangan absolut Pengadilan Agama; (b) Penguatan Sumber Daya Manusia (SDM) Peradilan Agama. Peradilan Agama mengalami pertumbuhan dan perkembangan dalam tentang waktu yang panjang sejak islam menjadi kekuatan politik di Indonesia. Sejalan dengan dinamika hukum yang semakin kompleks, Peradilan Agama berusaha tampil sebagai suatu institusi yang menjadi pilar bagi suksesnya penegakan supremasi hukum. karena itu, eksistensi Peradilan Agama perlu diperkuat dengan aturan normatif yang memberi otoritas yang luas (yuridksi) kepada Peradilan Agama.

Kewenangan Peradilan Agama yang semakin luas harus diimbangi dengan peningkatan sumber daya manusia (SDM). Aparatur pengadilan, sarana dan prasarana yang memadai, serta ketentuan hukum yang aplikatif.

Dengan demikian, paradigma baru Peradilan Agama benar-benar dapat menjawab tuntutan dan maslah hukum yang berkembang di masyarakat. Sebagai agent of change, 
sudah semestinya sumber daya Manusia di lingkugan peradilan Agama berkualitas, berdedikasi tinggi, bertanggung jawab, peduli, visioner, dan komunikatif,

Pengadaan sumber daya manusia (recruitment) di sini dapat diartikan dengan suatu proses kegiatan mengiasi formasi yang lowong, mulai dari perencanaan, pengumuman, pelamaran, penyaringan sempai dengan pengangkatan dan penempatan. Pegadaan yang dimaksud disini lebih luas maknanya, karen pengadaan dapat merupakan salah satu upaya dari pemanfaatan. Jadi, pengadaan disini adalah upaya penemuan calon dari dalam organisasi maupun dari luar untuk mengiasi jabatan yang memerlukan sumber daya manusia yang berkualitas. Jadi bisa berupa recruitment from outside dan recruitment from within.

Salah satu sumber daya yang penting dalam manajemen adalah sumber daya manusia atau human resources. Pentingnya sumber daya manusia ini, perlu didasari oleh semua tingkatan manajemen. Bagaimanapun majunya teknologi saat ini, namun faktor manusia tetap memegang peranan penting bagi keberhasilan suatu organisasi. Manajemen sumber daya manusia merupakan bagian yang penting, bahkan dapat dikatakan bahwa manajemen itu pada hakikatnya adalah manajemen sumber daya manusia atau manajemen sumber daya manusia adalah identik dengan manajemen itu sendiri.

Masa depan dan konstribusi lulusan jurusan hukum keluarga pada dasarnya tidak saja menjadi aparat peradilan Agama, tetapi dapat juga menjadi advokat yang beracara di pengadilan. Selama ini telah ada Surat Edaran Mahkamah Agung RI No, 1 Tahun 1998 tentang petunjuk pelaksanaan penerimaan Calon Pengacara Praktik yang memberikan Kesempatan Kepada Sarjana Syariah untuk menggeluti dunia Advokat. Munculnya UndangUndang Nomor 18 Tahun 2003 tentang Advokat yang membuka pintu bagi para Sarjana Hukum lslam (lulusan fakultas Syariah) untuk bergabung dalam praktik hukum.

Semua elemen merindukan tegaknya hukum yang benar, kerinduan tersebut dapat terobati jika proses hukum itu dijalankan atas dasar moral dengan menggunakan nilai-nilai agama, hal itu hanya dapat di realisasikan dengan merekrut sarjana lulusan jurusan hukum keluarga karena di samping menguasai ilmu hukum juga dibekali dengan moral dan agama. Harapan tersebut menjadi kenyataan ketika keluar undang-undang tentang advokat yang memberikan kesempatan kepada para alumni fakultas Syariah untuk menjadi advokat.

Akan tetapi perlu dipahami, bahwa Undang-Undang Nomor 18 Tahum 2003 tentang Advokat merupakan salah satu undang-undang kontroversial. Dikatakan demikian karena undang-undang ini resmi berlaku setelah diundangkan dalam lembaran negara tanpa ditandatangani (tanpa disahkan) oleh Presiden. Pada waktu itu, presiden menolak menandatanganinya karena menyamaratkan sarjana hukum dengan sarjan syariah. Dalam 
undang-undang ini sarjana syariah diperbolehkan menjadi advokat, yang dianggap akan menambah kacau penegakan hukum di Indonesia. Keluarnya pasal yang memberikan kesempatan kepada para alumni jurusan hukum keluarga sejajar dengan para lulusan sarjana hukum untuk menjadi advokat mengundang kontroversi karena fakultas Syariah dianggap tidak cukup membekali para mahasiswanya dalam bidang hukum, sekalipun mereka belajar beberapa materi hukum. Tentu saja penilaian seperti ini adalah peneilaian yang tidak berdasar, sangat subjektif serta tidak dapat dipertanggungjawabkan secara akademis. Perdebatan soal diperbolehkannya sarjana selain sarjana hukum untuk menggeluti profesi advokat memang seru sebagaimana di kemukakan oleh Hamdan Zoelva, Ketua Panitia Kerja RUU Advokat. Dinyatakan bahwa setelah melalui perdebatan panjang serta proses lobby antar fraksi dan pemerintah, persoalan ini diputuskan pada rapat pleno Komisi 11 bersama Menteri kehakiman dan HAM dengan mengakodomasi usulan diperbolehkannya sarjana syariah dan termasuk sarjana dari perguruan tinggi hukum lainnya (termasuk Sarjana Sekolah Tinggi Hukum Militer dan Sekolah Tinggi ilmu Kepolisian) untuk menjadi Advokat asal lulus seleksi menjadi Advokat. Berdasarkan Undang-Undang Advokat yang ada, tidak ada batasan peradilan mana yang boleh dimasuki oleh para Sarjana Syariah, mulai dari pengadilan Negeri (Peradilan Umum) hingga ke Mahkamah Agung. Namun begitu Advokat sarjana syariah lebih baik memfokuskan keahliannya pada peradilan Agama, artinya Peradilan Agama harus dipahami secara mendalam oleh para alumni jurusan hukum keluarga Fakultas Syariah baik secara teoretis maupun praktis. Otomatis apabila Peradilan Agama sebagai “daerah kekuasaan” para Sarjana Fakultas Syariah, maka bidang-bidang atau perkaraperkara yang menjadi trade mark mereka juga spesifik sifatnya. Memperdalam dan menguasai secara profesional terhadap keahlian khususnya dalam bidang hukum keluarga. Banyak harapan yang dapat ditumpangkan terhadap para lulusan Fakultas Syariah. Paling tidak ada dua alasan yang mendasarinya. Pertama, kuat dugaan bahwa para mahasiswa yang masuk ke fakultas ini adalah mereka yang memilki latar belakang agama relatif baik. Kondisi ini dapat dijadikan modal awal bagi terciptanya alumni yang berintegritas. Kedua, kurikulum Fakultas Syariah mestinya tetap mencerminkan ajaran-ajaran islam. Artinya, sekalipun para mahasiswa belajar soal "hukum dunia" tetapi mereka tetapmendapat bekal "hukum akhirat". Semestinya, dengan dua hal ini menjadikan alumni Fakultas Syariah menjadi "ahli hukum plus”. Paham soal hukum dunia dan hukum Tuhan, secara simultan juga memiliki akhlak yang baik.

Penguatan sumber daya manusia pada peradilan Agama, juga dilakukan dengan penyiapan regulasi yang diperlukan untuk mengisi kekosongan hukum, baik materil maupun 
formil di bidang hukum keluarga. Adapun upaya peningkatan kualitas para hakim Peradilan Agama ditempuh Mahkamah Agung dengan cara menyelenggarakan berbagai pelatihan dan bimbingan teknis. Mahkamah Agung juga mengadakan kerja sama dengan berbagai pihak, baik dalam maupun luar negeri, untuk memberi kesempatan para hakim Peradilan Agama memperdalam dan memperluas pemahaman tentang hukum keluarga islam.

Berdasarkan uraian tersebut, penyiapan sumber daya manusia (SDM) dan infrastruktur internal lembaga peradilan telah dilakukan dengan maksimal. Bahkan, penyiapan sumber daya manusia dan ifrastruktur internal lembaga peradilan sudah dilakukan sejak lahirnya Peradilan Agama, apalagi dengan lahirnya Undang-Undang Nomor 3 Tahun 2006 yang menambah kewenangan dan secara simultan penguatan terhadap kewenangan tersebut yang langsung direspons Mahkamah Agung, khususnya Urusan lingkungan Peradilan Agama (sekarang Kamar Perdata Agama) dan Direktorat Jenderal Badan Peradilan Agama. Secara garis besar, respons tersebut berupa dua langkah stertegis, yaitu penyiapan regulasi dan peningkatan kualitas para hakim Peradilan Agama.

\section{SIMPULAN}

Dari uraian di atas dapat disimpulkan hal-hal sebagai berikut; (a) Peran hukum keluarga (al-Ahwal al-Syakhsyiyah) dan fakultas Syariah/hukum Jurusan al-Ahwal alSyakhsyiyah menjadi sangat strategis karena melahirkan alumninya untuk berkiprah di bidang ilmu hukum dan praktisi hukum yang profesional dan beringtegritas sehingga mampu bersaing dalam berbagai ancaman dan tantangan yang pada gilirannya berkontribusi dalam penguatan sistem Peradilan Agama di indonesia; (b) Penguatan sistem peradilan Agama di lndonesia dan korelasinya dengan jurusan hukum keluarga (Ahwal al-Syakhsyiyah) dilakukan dengan dua hal penting, yaitu penguatan sistem hukum, dan penguatan sumber daya manusia. Dalam sudut pandang ini, sulit memisahkan antara jurusan hukum keluarga dengan penguatan sistem Peradilan Agama di Indonesia, Antara keduanya terdapat hubungan yang bersifat simbiosis mutualisme. Di mana perkembangan lembaga Peradilan Agama yang tumbuh pesat membutuhkan sistem hukum dan peradilan yang efektif guna menjamin terwujudnya kepastian hukum dan menjaga kepercayaan masyarakat maupun pihak lain yang terkait dengan kewenangannya terutama dalam bidang hukum keluarga.

\section{DAFTAR PUSTAKA}

Abd.Rauf. 1978. al-Qur'an dan ilmu Hukum. Jakarta:Bulan Bintang. Abdul Mana. 2008. Aneka Masalah Hukum Perdata Islam Indonesia. Jakarta: Kencana. 
Abdul Mana. 2006. Aspek-Aspek Pengubah Hukum. Jakarta: Kencana Prenada Media.

Amran Saudi dan Mardi Candra. 2016. Politik Hukum Perspektif Hukum Perdata dan Pidana lslam serta Ekonomi Syariah. Jakarta: Prenada Media Group.

Anton M. Moeliono. 1995. Kamus Besar Bahasa Indonesia. Jakarta: Balai Pustaka.

Bagir Manan. Peranan MARI dalam Menegakkan Supremasi Hukum. Makalah. PPS UNAND, Padang, 22 Januari 2002.

Cik Hasan Bisri. 2012. Peradilan Agama di Indonesia. Jakarta: Rajawali Pers.

Djazuli. 2006. Ilmu Fikih Penggalian, Perkembangan, dan Penerapan Hukum Islam. Jakarta: Kencana.

Djazuli. 2010. Kaidah-kaidah Fikih, Kaidah-Kaidah Hukum lslam dalam Menyelesaikan Masalah-Masalah yang Praktis. Jakarta: Kencana.

Hamdan Zoelva. "Undanf-Undang Advokat (Beberapa Catatan Perdebatan di DPR)".

lchtijanto. Prospek Peradilan Agama sebagai Peradilan Negara dalam Sistem Politik Hukum di Indonesia, dalam Amrullah Ahmad, et al. (Ed.).1996. Dimensi Hukum Islam dalam Sistem Hukum Nasional: Mengenang 65 Th. Prof. Dr. H. Busthanul Arifin, S.H. Jakarta: Gema Insani Press.

John L. Esposito. 2001. Women in Muslim Family Law. New York: Syracuse University Press.

Joseph Schacht. 1982. An lntroduction tp lslamic Law. Oxford University Press.

Lama Abu Odeh. 2004. Modernizing Muslim Family Law: The Case of Egypt dalam Vanderbit Journal of Transnational Law. Vol, 37.

Lawrence M. Friedman. 1975. The Legal System. New York: Russel Sage Fondation.

Logemen, J.H.A. 1954. Over de Teori Van den Stellingstaats Recht. Jakarta: Saksama.

M. Atho Muzahar. 2000. Membaca Gelombang Ijtihad: Antara Tradisi dan Liberalisasi. Jakarta: Gema Insani.

M. Hadi Shubhan, S.H., M.H., C.N. "Sarjana Syariah Tak Layak Jadi Advokat?". Harian Surya. Internet:http://www.surya.co.id/20062003/12a.phtml

Pedmo Wahjono. Budaya Hukum Islam dalam Perspektif Pembentukan Hukum di Masa Datang, dalam Amrullah Ahmad, et al. (Ed.). 1996. Dimensi Hukum Islam dalam Sistem Hukum Nasional: Mengenang 65 Th. Prof. Dr. H. Busthanul Arifin, S.H. Jakarta: Gema Insani Press.

Said Agil Al-Munawar. 2004. Hukum Islam dan Pluralitas Sosial. Jakarta: Paramadina.

Sajuti Thalib. 1985. Receptio A Contratrio, Hubungan Hukum Adat dan Hukum Islam. Jakarta: Bina Aksara.

Satjipto Raharjo. Pengadilan Agama sebagai Pengadilan Keluarga, dalam Amrullah Ahmad. 1996. Dimensi Hukum Islam dalam Sistem Hukum Nasional. Jakarta: Gema Insani.

Warnoto. 2008. Politik Hukum Islam di Indonesia. Yogyakarta: Fakultas Syariah Press UIN Sunan Kalijaga.

ZainunBuchari. 2001. Manajemen dan Motivasi. Jakarta: Balai Aksara. 